\title{
Total Synthesis and Preliminary Biological Evaluation of cis-Solamin Isomers:
}

\section{Supporting Information File}

Alex R. L. Cecil, ${ }^{a}$ Yulai Hu, ${ }^{a}$ Maria J. Vicent, ${ }^{b}$ Ruth Duncan, ${ }^{b}$ and Richard C. D. Brown*a

${ }^{a}$ Department of Chemistry, The University of Southampton, Highfield, Southampton SO17 1BJ, UK.

${ }^{b}$ Center for Polymer Therapeutics, Welsh School of Pharmacy, King Edward VII Ave., Redwood Building, Cardiff University CF10 3XF, UK.

Corresponding author email: $\underline{\text { rcb1@ } \text { soton.ac.uk }}$

\begin{tabular}{|c|c|}
\hline $\mathrm{S} 1$ & Index \\
\hline $\mathrm{S} 2$ & Experimental and data for $\mathbf{1 1}$ \\
\hline $\mathrm{S} 2$ & Experimental and data for $\mathbf{1 2}$ \\
\hline S3 & Experimental and data for $\mathbf{1 3}$ \\
\hline S3 & Experimental for 7 \\
\hline $\mathrm{S} 4$ & Experimental and data for $\boldsymbol{e n t} \mathbf{- 7}$ \\
\hline $\mathrm{S} 4$ & Experimental and data for ent-21 \\
\hline $\mathrm{S} 4$ & Experimental and data for $\boldsymbol{e n t}-\mathbf{2 2}$ \\
\hline $\mathrm{S} 4$ & Experimental and data for $\boldsymbol{e n t} \mathbf{- 2 3}$ \\
\hline $\mathrm{S} 4$ & Experimental and data for ent-3 \\
\hline S5 & Experimental and data for ent-24 \\
\hline S5 & Experimental and data for 27 \\
\hline S5 & Experimental and data for $\boldsymbol{e n t}-\mathbf{2 7}$ \\
\hline S6 & Experimental and data for $\mathbf{1 5}$ \\
\hline S7 & Protocols for In Vitro Studies \\
\hline S8 & Figure 1. $\mathrm{IC}_{50}$ values against $\mathrm{B} 16 \mathrm{~F} 1$ \\
\hline S8 & Figure 2. 1h Red Blood Cell Lysis $A$ \\
\hline S9 & General Experimental \\
\hline S10 & ${ }^{1} \mathrm{H}$ NMR for cis-solamin (1) \\
\hline S11 & ${ }^{13} \mathrm{C}$ NMR for cis-solamin (1) \\
\hline $\mathrm{S} 12$ & ${ }^{1} \mathrm{H}$ NMR for compound 5 \\
\hline S13 & ${ }^{13} \mathrm{C}$ NMR for compound 5 \\
\hline S14 & ${ }^{1} \mathrm{H}$ NMR for compound $\mathbf{1 6}$ \\
\hline S15 & ${ }^{13} \mathrm{C}$ NMR for compound $\mathbf{1 6}$ \\
\hline S16 & ${ }^{1} \mathrm{H}$ NMR for compound 25 \\
\hline S17 & ${ }^{13} \mathrm{C}$ NMR for compound 25 \\
\hline S18 & Chiral HPLC trace for $\mathbf{1}$ and $\mathbf{2}$ \\
\hline
\end{tabular}


(4E)-Heptadec-4-enal (11)

To a solution of ethyl (3E)-heptadec-3-enoate (10) ${ }^{1}(2.00 \mathrm{~g}, 7.1 \mathrm{mmol})$ in $\mathrm{CH}_{2} \mathrm{Cl}_{2}(160 \mathrm{~mL})$ at $-78^{\circ} \mathrm{C}$ was added dropwise DIBAL-H (9.2 $\mathrm{mL}$ of a $1 \mathrm{M}$ solution in hexane, $9.2 \mathrm{mmol})$ over $20 \mathrm{~min}$. After $3 \mathrm{~h} \mathrm{MeOH} \mathrm{(40}$ $\mathrm{mL})$ was added followed by $\mathrm{H}_{2} \mathrm{O}(40 \mathrm{~mL})$ and $\mathrm{HCl}(20 \mathrm{~mL}$ of $2 \mathrm{M})$ after a further $5 \mathrm{~min}$. The organic layer was separated and the aqueous layer re-extracted with $\mathrm{CH}_{2} \mathrm{Cl}_{2}(2 \times 50 \mathrm{~mL})$. The combined organic fractions were dried $\left(\mathrm{Na}_{2} \mathrm{SO}_{4}\right)$ and concentrated in vacuo to give a colourless oil $(1.72 \mathrm{~g})$. Purification by column chromatography $\left(\mathrm{SiO}_{2}\right)$ eluting with EtOAc/hexane (2.5:97.5 then 3:97) gave aldehyde (11) (1.57 g, 6.2 $\mathrm{mmol}, 88 \%$ ) as a white solid. Spectroscopic data were consistent with those previously reported. ${ }^{2} \mathrm{mp} 34-36$ ${ }^{\circ} \mathrm{C}$; IR $v_{\max }$ (neat) 2924, 2853, 1735, 1365, $1217(\mathrm{~s}) \mathrm{cm}^{-1}$; ${ }^{1} \mathrm{H}$ NMR $\left(400 \mathrm{MHz}, \mathrm{CDCl}_{3}\right) \square 9.77(1 \mathrm{H}, \mathrm{t}, J=1.7$ $\mathrm{Hz}, \mathrm{CHO}), 5.47(1 \mathrm{H}, \mathrm{td}, J=6.3,15.3 \mathrm{~Hz}, \mathrm{CH}=\mathrm{CH}), 5.40(1 \mathrm{H}, \mathrm{td}, J=6.8,15.3 \mathrm{~Hz}, \mathrm{CH}=\mathrm{CH}), 2.52-2.47(2 \mathrm{H}$, m, $\left.\mathrm{CH}_{2} \mathrm{CHO}\right), 2.34\left(2 \mathrm{H}\right.$, br q, $\left.J=6.8 \mathrm{~Hz}, \mathrm{CH}_{2}\right), 1.96\left(2 \mathrm{H}\right.$, br q, $\left.J=6.8 \mathrm{~Hz}, \mathrm{CH}_{2}\right), 1.37-1.22\left(20 \mathrm{H}, \mathrm{m}, \mathrm{CH}_{2}\right)$, $0.89\left(3 \mathrm{H}, \mathrm{t}, J=7.0 \mathrm{~Hz}, \mathrm{CH}_{3}\right) ;{ }^{13} \mathrm{C}$ NMR $\left(100 \mathrm{MHz}, \mathrm{CDCl}_{3}\right) \square 202.5,132.3,127.7,43.7,32.6,32.1,29.8$, 29.6, 29.5, 29.3, 25.3, 22.8, 14.2; LRMS (GCEI) $\mathrm{m} / z 252\left(\mathrm{M}^{+*}, 5 \%\right), 84$ (100\%); Elemental calcd for $\mathrm{C}_{16} \mathrm{H}_{30} \mathrm{O}: \mathrm{C}, 80.88 ; \mathrm{H}, 12.78$. Found, $\mathrm{C}, 80.85 ; \mathrm{H}, 12.73$.

\section{(2E,6E)-Nonadeca-2,6-dienoic acid ethyl ester (12)}

To a solution of ethyl (3E)-heptadec-3-enoate $(\mathbf{1 0})^{1}(2.00 \mathrm{~g}, 6.8 \mathrm{mmol})$ in $\mathrm{CH}_{2} \mathrm{Cl}_{2}(80 \mathrm{~mL})$ at $-60{ }^{\circ} \mathrm{C}$ was added dropwise DIBAL-H ( $8.4 \mathrm{~mL}$ of $1 \mathrm{M}$ solution in hexane, $8.4 \mathrm{mmol}$ ) over $20 \mathrm{~min}$. The reaction mixture was stirred for $2 \mathrm{~h}$ then allowed to warm to $-40^{\circ} \mathrm{C}$ whereupon it was transferred via canula into a solution of the sodium salt of triethyl phosphonoacetate in THF $(50 \mathrm{~mL})$ at $-40^{\circ} \mathrm{C}$ [prepared by deprotonation of triethyl phosphonoacetate $(2.0 \mathrm{~mL}, 10.0 \mathrm{mmol})$ with $\mathrm{NaH}(0.40 \mathrm{~g}, 10 \mathrm{mmol}, 60 \%$ in mineral oil $)]$. After $30 \mathrm{~min}$ the solution was allowed to warm to rt over $1 \mathrm{~h}$, then water $(100 \mathrm{~mL}), 1 \mathrm{M} \mathrm{HCl}(20 \mathrm{~mL})$ and ether $(250 \mathrm{~mL})$ were added. The organic phase was separated and the aqueous phase re-extracted with ether $(3 \times 50 \mathrm{~mL})$. The combined organic phase was dried $\left(\mathrm{MgSO}_{4}\right)$ and concentrated in vacuo to give a yellow oil $(2.5 \mathrm{~g})$. Purification by column chromatography $\left(\mathrm{SiO}_{2}\right.$, EtOAc/hexane 1:65) gave the title dienoate $\mathbf{1 2}(2.10 \mathrm{~g}, 6.5$ mmol, 96\%) as a colourless oil. Spectroscopic data were consistent with those previously reported. ${ }^{2}$ IR $v_{\max }$ (neat) 2921(s), 1724(s), 1654(m), 1266(m), 1173(m), 1047(m) cm ${ }^{-1} ;{ }^{1} \mathrm{H}$ NMR (300 MHz) $\square 6.96(1 \mathrm{H}, \mathrm{td}, J=$ 6.6, $\left.15.6 \mathrm{~Hz}, \mathrm{CH}=\mathrm{CHCO}_{2} \mathrm{Et}\right), 5.82\left(1 \mathrm{H}, \mathrm{td}, J=1.5,15.6 \mathrm{~Hz}, \mathrm{CHCO}_{2} \mathrm{Et}\right), 5.45(1 \mathrm{H}, \operatorname{td} J=6.2,15.3 \mathrm{~Hz}$, $\mathrm{CH}=\mathrm{CH}, 5.37(1 \mathrm{H}, \mathrm{td}, J=6.2,15.3 \mathrm{~Hz}, \mathrm{CH}=\mathrm{CH}), 4.18\left(2 \mathrm{H}, \mathrm{q}, J=7.2 \mathrm{~Hz}, \mathrm{CH}_{2} \mathrm{O}\right), 2.31-2.21(2 \mathrm{H}, \mathrm{m}$, $\left.\mathrm{CH}_{2} \mathrm{CH}=\mathrm{CH}\right), 2.20-2.10\left(2 \mathrm{H}, \mathrm{m}, \mathrm{CH}_{2} \mathrm{CH}=\mathrm{CH}\right), 1.96\left(2 \mathrm{H}, \mathrm{q}, J=6.2 \mathrm{~Hz}, \mathrm{CH}_{2} \mathrm{CH}=\mathrm{CH}\right), 1.40-1.16(23 \mathrm{H}, \mathrm{m})$, $0.88\left(3 \mathrm{H}, \mathrm{t}, J=6.4 \mathrm{~Hz}, \mathrm{CH}_{3}\right) ;{ }^{13} \mathrm{C} \mathrm{NMR}(75 \mathrm{MHz}) \square 166.9 \mathrm{C}, 148.9 \mathrm{CH}, 132.0 \mathrm{CH}, 128.5 \mathrm{CH}, 121.6 \mathrm{CH}$, 60.3 $\mathbf{C H}_{2}, 32.7 \mathbf{C H}_{2}, 32.4 \mathbf{C H}_{2}, 32.1 \mathbf{C H}_{2}, 31.2 \mathbf{C H}_{2}, 29.8 \mathbf{C H}_{2}, 29.7 \mathbf{C H}_{2}, 29.5 \mathbf{C H}_{2}, 29.3 \mathbf{C H}_{2}, 22.9 \mathbf{C H}_{2}$, 14.4 $\mathrm{CH}_{3}, 14.3 \mathrm{CH}_{3}$.

\footnotetext{
${ }^{1}$ Jan, S.-T.; Li, K.; Vig, S.; Rudolph, A.; Uckun, F. M. Tetrahedron Lett. 1999, 40, 193-196.

${ }^{2}$ Makabe, H.; Tanimoto, H.; Tanaka, A.; Oritani, T. Heterocycles, 1996, 43, 2229-2248.
} 
(2E,6E)-Nonadeca-2,6-dienoic acid (13)

To a solution of ester $\mathbf{1 2}(1.77 \mathrm{~g}, 5.5 \mathrm{mmol})$ in $\mathrm{MeOH}(9 \mathrm{~mL})$ was added a solution of $\mathrm{NaOH}(1.18 \mathrm{~g}, 30$ $\mathrm{mmol})$ and $\mathrm{NaHCO}_{3}(0.23 \mathrm{~g}, 3.0 \mathrm{mmol})$ in water $(30 \mathrm{~mL})$. The solution was refluxed for $5 \mathrm{~h}$, after cooling to $0^{\circ} \mathrm{C}$ the reaction was quenched with $10 \%$ aqueous citric acid $(100 \mathrm{~mL})$. Ether $(200 \mathrm{~mL})$ was added and the organic phase separated, was re-extracting the aqueous phase with ether $(2 \times 50 \mathrm{~mL})$. The combined organic phase was dried $\left(\mathrm{MgSO}_{4}\right)$ and concentrated in vacuo to give dienoic acid 13 (1.60 g, $\left.5.4 \mathrm{mmol}, 98 \%\right)$ as a white solid that required no further purification. mp $63-65{ }^{\circ} \mathrm{C}$; IR $v_{\max }$ (neat) $3580(\mathrm{br}), 1694(\mathrm{~s}), 1660(\mathrm{~s})$, 1469(m), 1373(m), 1289(m), 1250(m), 1214(m); ${ }^{1} \mathrm{H}$ NMR (300 MHz, DMSO) $\square 12.36$ (1H, br, COOH), 6.78 $\left(1 \mathrm{H}, \mathrm{td}, J=6.7,15.7 \mathrm{~Hz}, \mathrm{CH}=\mathrm{CHCO}_{2} \mathrm{H}\right), 5.75\left(1 \mathrm{H}, \mathrm{d}, J=15.6 \mathrm{~Hz}, \mathrm{CHCO}_{2} \mathrm{H}\right), 5.42(1 \mathrm{H}, \operatorname{td} J=6.6,15.3 \mathrm{~Hz}$, $\mathrm{CH}=\mathrm{CH}, 5.35(1 \mathrm{H}, \mathrm{td}, J=6.6,15.3 \mathrm{~Hz}, \mathrm{CH}=\mathrm{CH}), 2.28-2.16\left(2 \mathrm{H}, \mathrm{m}, \mathrm{CH}_{2} \mathrm{CH}=\mathrm{CH}\right), 2.15-2.05(2 \mathrm{H}, \mathrm{m}$, $\left.\mathrm{CH}_{2} \mathrm{CH}=\mathrm{CH}\right), 2.00-1.88\left(2 \mathrm{H}, \mathrm{m}, \mathrm{CH}_{2} \mathrm{CH}=\mathrm{CH}\right), 1.40-1.15(20 \mathrm{H}, \mathrm{m}), 0.85\left(3 \mathrm{H}, \mathrm{t}, J=6.5 \mathrm{~Hz}, \mathrm{CH}_{3}\right) ;{ }^{13} \mathrm{C}$ NMR (75 MHz, DMSO) $\square$ 167.1 C, 148.2 CH, 130.9 CH, 128.7 CH, 122.1 CH, 31.9 CH$_{2}, 31.3 \mathbf{C H}_{2}, 30.4$ $\mathbf{C H}_{2}, 29.0 \mathbf{C H}_{2}, 28.9 \mathbf{C H}_{2}, 28.8 \mathbf{C H}_{2}, 28.7 \mathbf{C H}_{2}, 28.4 \mathbf{C H}_{2}, 22.1 \mathbf{C H}_{2}, 13.9 \mathbf{C H}_{3}$; LRMS (ES $) \mathrm{m} / z 293$ (100\%, [M-H] ; Elemental calcd. For $\mathrm{C}_{19} \mathrm{H}_{34} \mathrm{O}_{2}: \mathrm{C}, 77.50 ; \mathrm{H}, 11.64$. Found: C, 77.38; H, 11.53.

\section{(2S)- $N$-((2E,6E)-2,6-nonadecadienoyl)-camphor-10,2-sultam (7)}

From acid 13: To an ice-cooled solution of dienoic acid $13(2.23 \mathrm{~g}, 7.7 \mathrm{mmol})$ and oxalyl chloride $(0.81 \mathrm{~mL}$, $9.2 \mathrm{mmol})$ in $\mathrm{CH}_{2} \mathrm{Cl}_{2}(30 \mathrm{~mL})$ were added two drops of DMF. The mixture was stirred for $2 \mathrm{~h}$ before being concentrated in vacuo and then re-disolved in $\mathrm{CH}_{2} \mathrm{Cl}_{2}(2 \mathrm{~mL})$. In a separate flask $\mathrm{NaH}(0.339 \mathrm{~g}$ of a $60 \%$ dispersion in mineral oil, $8.5 \mathrm{mmol}$ ) was added to a solution of (2S)-camphor10,2-sultam (1.82 $\mathrm{g}, 8.5 \mathrm{mmol})$ in $\mathrm{CH}_{2} \mathrm{Cl}_{2}(20 \mathrm{~mL})$ CAUTION: evolution of $\mathbf{H}_{2}$ gas. After $10 \mathrm{~min}$ the solution of the sodium salt was cooled to $0^{\circ} \mathrm{C}$ and the acid chloride solution (prepared above) added dropwise. After $1 \mathrm{~h}$ water $(5 \mathrm{~mL})$, brine $(5 \mathrm{~mL})$ and $\mathrm{CH}_{2} \mathrm{Cl}_{2}(20 \mathrm{~mL})$ were added and the organic phase was separated, re-extracting the aqueous phase with $\mathrm{CH}_{2} \mathrm{Cl}_{2}(2 \times 20 \mathrm{~mL})$. The organic solution was dried $\left(\mathrm{MgSO}_{4}\right)$ and concentrated in vacuo. Purification by column chromatography $\left(\mathrm{SiO}_{2}, \mathrm{Et}_{2} \mathrm{O} /\right.$ hexane $1: 9$ then 1:4) gave the title diene $7(3.03 \mathrm{~g}, 6.2 \mathrm{mmol}, 80 \%)$ as a white solid. A sample was recrystallized from hexane to give colourless prisms. Characterization data can be found in the printed version of this article. 
(2R)-N-((2E,6E)-2,6-nonadecadienoyl)-camphor-10,2-sultam (ent-7)

Following the method described for the preparation of 7 from 13: reaction of acid $\mathbf{1 3}$ (2.00 g, $6.89 \mathrm{mmol})$ with the (2R)-camphor10,2-sultam (1.63 g, $7.60 \mathrm{mmol})$ gave the title diene ent-7 (2.78 g, $5.65 \mathrm{mmol}, 82 \%)$ as a white solid: $\mathrm{mp} 41-44{ }^{\circ} \mathrm{C}$; [ $\left.\mathrm{C}\right]^{24}{ }_{\mathrm{D}}-61.1\left(\mathrm{CHCl}_{3}, c 0.40\right)$; Elemental calcd. for $\mathrm{C}_{29} \mathrm{H}_{49} \mathrm{NO}_{3} \mathrm{~S}: \mathrm{C}, 70.83$; $\mathrm{H}$, $10.01 ; \mathrm{N}, 2.85$. Found: C, 70.69; H, 9.95; N, 2.83. Other spectroscopic data were identical to those reported for the enantiomer 7.

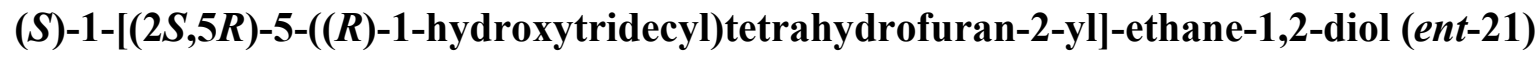

Following the method described for the preparation of 21: reduction acylsultam 16 (250 mg, $0.46 \mathrm{mmol}$ )

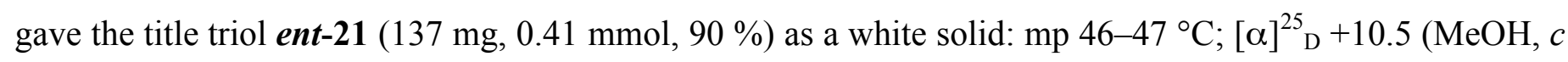
0.40); Elemental calcd. for $\mathrm{C}_{19} \mathrm{H}_{38} \mathrm{O}_{4}: \mathrm{C}, 69.05 ; \mathrm{H}, 11.59$. Found: $\mathrm{C}, 68.93 ; \mathrm{H}, 11.42$. Other spectroscopic data were identical with that reported for the enantiomer 21.

\section{(S)-2-hydroxy-2-[(2S,5R)-5-((R)-1-hydroxytridecyl)-tetrahydrofuran-2-yl]-ethyl 4-}

\section{methylbenzenesulfonate (ent-22)}

Following the method described for the preparation of 22: tosylation of triol ent-21 (128 $\mathrm{mg}, 0.39 \mathrm{mmol}$ ) gave the title tosylate $\boldsymbol{e n t - 2 2}(185 \mathrm{mg}, 0.38 \mathrm{mmol}, 98 \%)$ as a white solid. $\mathrm{mp} 70-72{ }^{\circ} \mathrm{C}$; [ []$^{25}{ }_{\mathrm{D}}+10.6\left(\mathrm{CHCl}_{3}\right.$, c 0.36); Elemental calcd. for $\mathrm{C}_{26} \mathrm{H}_{44} \mathrm{O}_{6} \mathrm{~S}: \mathrm{C}, 64.43 ; \mathrm{H}, 9.15$. Found: $\mathrm{C}, 64.34 ; \mathrm{H}, 9.05$. Other spectroscopic data were identical with that reported for the enantiomer 22.

\section{(R)-1-[(2R,5S)-5-((S)oxiran-2-yl)-tetrahydrofuran-2-yl]-tridecan-1-ol (ent-23)}

Following the method described for the preparation of 23: reaction of tosylate ent-22 (180 $\mathrm{mg}, 0.37 \mathrm{mmol})$ gave the title epoxide ent-23 (111 mg, $0.36 \mathrm{mmol}, 96 \%)$ as a white solid. mp $37-40{ }^{\circ} \mathrm{C}$; $[\mathrm{C}]^{20}{ }_{\mathrm{D}}+10.3$ $\left(\mathrm{CHCl}_{3}, c\right.$ 0.62); Elemental calcd. for $\mathrm{C}_{19} \mathrm{H}_{36} \mathrm{O}_{3}$ : C, 73.03; H, 11.61. Found: $\mathrm{C}, 73.01 ; \mathrm{H}, 11.57$. Other spectroscopic data were identical with that reported for the enantiomer 23.

\section{(1S)-1-[(2S,5R)-5-((1R)-1-hydroxytridecyl)-tetrahydrofuran-2-yl]-12-tridecen-1-ol (ent-3)}

Following the method described for the preparation of 3: reaction of epoxide ent-23 (96 mg, $0.31 \mathrm{mmol})$ gave the title olefin ent-3 $(127 \mathrm{mg}, 0.27 \mathrm{mmol}, 88 \%)$ as a white solid. mp $55-57^{\circ} \mathrm{C}$; [ []$^{25}{ }_{\mathrm{D}}+0.9\left(\mathrm{CHCl}_{3}, c\right.$ 1.1); Elemental calcd. for $\mathrm{C}_{30} \mathrm{H}_{58} \mathrm{O}_{3}: \mathrm{C}, 77.19 ; \mathrm{H}, 12.52$. Found: $\mathrm{C}, 77.24 ; \mathrm{H}, 12.31$. Other spectroscopic data were identical with that reported for the enantiomer 3 . 
$(5 R)-3-((E, 13 S)-13-h y d r o x y-13-(2 S, 5 R)-5-[(1 R)-1-h y d r o x y t r i d e c y l]$ tetrahydro-2-furanyl-2-tridecenyl)-

\section{5-methyl-2,5-dihydro-2-furanone (ent-24)}

Following the method described for the preparation of 24: ruthenium-catalyzed Alder-ene reaction of olefin ent-3 (45 mg, $0.10 \mathrm{mmol}$ ) and alkyne ent-4 (19 $\mathrm{mg}, 0.14 \mathrm{mmol})$ gave the title butenolide ent-24 (39 $\mathrm{mg}$, $0.06 \mathrm{mmol}, 70 \%)$ as a white solid: $\mathrm{mp} 63-65{ }^{\circ} \mathrm{C}$; [ []$^{24}{ }_{\mathrm{D}}-8.9(\mathrm{MeOH}, c$ 0.42); Elemental calcd. for $\mathrm{C}_{35} \mathrm{H}_{62} \mathrm{O}_{5}$ : C, 74.68; H, 11.10. Found: $\mathrm{C}, 74.59 ; \mathrm{H}, 11.02$. The ${ }^{1} \mathrm{H}$ NMR, ${ }^{13} \mathrm{C}$ NMR, IR and MS data for compound ent-24 were indistiguishable from that of $\mathbf{2 4}$.

(5S)-3-((E,13S)-13-hydroxy-13-(2S,5R)-5-[(1R)-1-hydroxytridecyl]tetrahydro-2-furanyl-2-tridecenyl)-

\section{5-methyl-2,5-dihydro-2-furanone (27)}

Following the method described for the preparation of 24: ruthenium-catalyzed Alder-ene reaction of olefin ent-3 (45 mg, $0.10 \mathrm{mmol}$ ) and alkyne $4(19 \mathrm{mg}, 0.14 \mathrm{mmol})$ gave the title butenolide 27 (36 mg, $0.06 \mathrm{mmol}$, $66 \%$ ) as a white solid: $\mathrm{mp} 64-67^{\circ} \mathrm{C}$; [ []$^{24}{ }_{\mathrm{D}}+9.3\left(\mathrm{MeOH}, c\right.$ 0.48); Elemental calcd. for $\mathrm{C}_{35} \mathrm{H}_{62} \mathrm{O}_{5}$ : C, 74.68 ;

H, 11.10. Found: C, 74.61; H, 11.08. The ${ }^{1} \mathrm{H}$ NMR, ${ }^{13} \mathrm{C}$ NMR, IR and MS data for compound 27 were indistiguishable from that of $\mathbf{2 4}$.

(5R)-3-((E,13R)-13-hydroxy-13-(2R,5S)-5-[(1S)-1-hydroxytridecyl]tetrahydro-2-furanyl-2-tridecenyl)-

\section{5-methyl-2,5-dihydro-2-furanone (ent-27)}

Following the method described for the preparation of 24: ruthenium-catalyzed Alder-ene reaction of olefin ent-3 (40 mg, $0.09 \mathrm{mmol})$ and alkyne ent-4 (16 mg, $0.11 \mathrm{mmol})$ gave the title butenolide ent-27 (34 $\mathrm{mg}, 0.06$ mmol, $70 \%$ ) as a white solid: $\mathrm{mp} 63-65{ }^{\circ} \mathrm{C}$; $[\square]^{24}{ }_{\mathrm{D}}-8.3(\mathrm{MeOH}, c 0.54)$; Elemental calcd. for $\mathrm{C}_{35} \mathrm{H}_{62} \mathrm{O}_{5}$ : $\mathrm{C}$, 74.68; H, 11.10. Found: C, 74.64; H, 11.07. The ${ }^{1} \mathrm{H}$ NMR, ${ }^{13} \mathrm{C}$ NMR, IR and MS data for compound ent-27 were indistiguishable from that of $\mathbf{2 4}$. 
(2S)-N-(2-(Diethylphosphonyl)-acetyl)-camphor-10,2-sultam (15)

Under an atmosphere of $\mathrm{N}_{2}$ at $\mathrm{rt}$, to a solution of $(2 \mathrm{~S})$-camphor10,2-sultam (7.00 g, $\left.32.5 \mathrm{mmol}\right)$ in $\mathrm{CH}_{2} \mathrm{Cl}_{2}$ $(300 \mathrm{~mL})$ was added in several batches $\mathrm{NaH}(1.30 \mathrm{~g}$ of a $60 \%$ suspension in mineral-oil, $32.5 \mathrm{mmol})$ CARE: evolution of $\mathbf{H}_{2}$ (g). After 30 min the reaction was cooled to $-60{ }^{\circ} \mathrm{C}$ whereupon chloroacetyl chloride $(3.11$ $\mathrm{mL}, 39 \mathrm{mmol}$ ) was added dropwise. The reaction was allowed to warm to rt over $2 \mathrm{~h}$, whereupon $\mathrm{NH}_{4} \mathrm{Cl}(\mathrm{sat}$ aq, $50 \mathrm{~mL})$ and $\mathrm{H}_{2} \mathrm{O}(100 \mathrm{~mL})$ were added. The organic layer was separated and the aqueous layer reextracted with $\mathrm{CH}_{2} \mathrm{Cl}_{2}(2 \times 75 \mathrm{~mL})$. The combined organic fractions were washed with $\mathrm{NaHCO}_{3}(\mathrm{sat}$ aq, 40 $\mathrm{mL}$ ) before being dried $\left(\mathrm{MgSO}_{4}\right)$ and concentrated in vacuo to give a white solid (9 g). Purification by column chromatography $\left(\mathrm{SiO}_{2}\right.$, eluting with EtOAc/hexane, 1:7) gave (2S)-N-(2-Chloroacetyl)-camphor10,2-sultam $(8.53 \mathrm{~g}, 29.3 \mathrm{mmol}, 91 \%)$ as a white crystalline solid. mp $120-122{ }^{\circ} \mathrm{C}$; IR $v_{\max }$ (neat) 2953, 1699, 1323, 1267, 1235, 1213, 1132; ${ }^{1} \mathrm{H}$ NMR (300 MHz, $\left.\mathrm{CDCl}_{3}\right) \square 4.51\left(2 \mathrm{H}, \mathrm{s}, \mathrm{CH}_{2} \mathrm{Cl}\right), 3.92(1 \mathrm{H}, \mathrm{dd}, J=$ 5.1, 7.5 Hz, CHN), $3.54\left(1 \mathrm{H}, \mathrm{d}, J=13.8 \mathrm{~Hz}, \mathrm{CHHSO}_{2}\right), 3.47\left(1 \mathrm{H}, \mathrm{d}, J=13.8 \mathrm{~Hz}, \mathrm{CHHSO}_{2}\right), 2.24-2.04(2 \mathrm{H}$, m, $\left.\mathrm{CH}_{2} \mathrm{CHN}\right), 2.01-1.82(3 \mathrm{H}, \mathrm{m}), 1.49-1.31(2 \mathrm{H}, \mathrm{m}), 1.15\left(3 \mathrm{H}, \mathrm{s}, \mathrm{CH}_{3} \mathrm{C}\right), 0.98\left(3 \mathrm{H}, \mathrm{s}, \mathrm{CH}_{3} \mathrm{C}\right) ;{ }^{13} \mathrm{C}$ NMR $(75$ $\mathrm{MHz}) \square 164.8(\mathrm{C}), 65.6(\mathrm{CH}), 52.8\left(\mathrm{CH}_{2}\right), 49.3(\mathrm{C}), 48.0(\mathrm{C}), 44.6(\mathrm{CH}), 42.5\left(\mathrm{CH}_{2}\right), 38.1\left(\mathrm{CH}_{2}\right), 32.9\left(\mathrm{CH}_{2}\right)$, $26.5\left(\mathrm{CH}_{2}\right), 20.9\left(\mathrm{CH}_{3}\right), 20.0\left(\mathrm{CH}_{3}\right) ; \mathrm{LRMS}(\mathrm{ES}+) \mathrm{m} / z, 314\left(100 \%,[\mathrm{M}+\mathrm{Na}]^{+}\right), 292\left(90 \%,[\mathrm{M}+\mathrm{H}]^{+}\right)$; Elemental calcd. for $\mathrm{C}_{12} \mathrm{H}_{18} \mathrm{O}_{3} \mathrm{NSCl}$ : C, 49.40; H, 6.22; N, 4.80. Found: C, 49.22; H, 5.99; N, 4.66.

Under an atmosphere of $\mathrm{N}_{2}$ a solution of (2S)- $N$-(2-Chloroacetyl)-camphor-10,2-sultam (7.30 g, $\left.26.3 \mathrm{mmol}\right)$ and triethyl phosphite $(6.85 \mathrm{~mL}, 39.9 \mathrm{mmol})$ in xylenes was refluxed for $48 \mathrm{~h}$. The solution was concentrated in vacuo to give a yellow oil. Excess triethyl phosphite was removed under vacuum $\left(0.5\right.$ mbar, $\left.150{ }^{\circ} \mathrm{C}\right)$. Purification by column chromatography $\left(\mathrm{SiO}_{2}\right.$, eluting with EtOAc/hexane, 1:3 to 4:1) gave phophonate 15 $(8.58 \mathrm{~g}, 21.8 \mathrm{mmol}, 83 \%)$ as a colourless oil. [ []$_{\mathrm{D}}^{25}+58.9\left(\mathrm{CHCl}_{3}, c\right.$ 1.0); IR $v_{\max }$ (neat) 2962, 1692, 1329, 1257, 1169, $1134 \mathrm{~cm}^{-1} ;{ }^{1} \mathrm{H}-\mathrm{NMR}\left(400 \mathrm{MHz}, \mathrm{CDCl}_{3}\right) \square 4.24-4.11\left(4 \mathrm{H}, \mathrm{m}, \mathrm{OCH}_{2} \mathrm{CH}_{3} \times 2\right), 3.88(1 \mathrm{H}, \mathrm{dd}, J=$ 5.0, 7.8 Hz, CHN), $3.56(1 \mathrm{H}, \mathrm{dd}, J=15.6,22.6 \mathrm{~Hz}, \mathrm{PCHH}), 3.50\left(1 \mathrm{H}, J=13.8 \mathrm{~Hz}, \mathrm{CHHSO}_{2}\right), 3.43(1 \mathrm{H}, \mathrm{d}, J$ $\left.=13.8 \mathrm{~Hz}, \mathrm{CHHSO}_{2}\right), 3.19(1 \mathrm{H}, \mathrm{dd}, J=15.6,22.6 \mathrm{~Hz}, \mathrm{PCHH}), 2.20-2.03\left(2 \mathrm{H}, \mathrm{m}, \mathrm{CH}_{2} \mathrm{CHN}\right), 1.97-1.77(3 \mathrm{H}$, m), 1.45-1.22 (2H, m), $1.33\left(6 \mathrm{H}, \mathrm{dt}, J=2.8,7.3 \mathrm{~Hz}, \mathrm{CH}_{3} \mathrm{CH}_{2}\right), 1.17\left(3 \mathrm{H}, \mathrm{s}, \mathrm{CH}_{3} \mathrm{C}\right), 0.96\left(\left(3 \mathrm{H}, \mathrm{s}, \mathrm{CH}_{3} \mathrm{C}\right) ;{ }^{13} \mathrm{C}-\right.$ NMR (100 MHz, $\left.\mathrm{CDCl}_{3}\right) \square 163.7\left(\mathrm{~d}, J_{p}=6.8 \mathrm{~Hz}, \mathrm{C}\right), 65.4(\mathrm{CH}), 62.9\left(\mathrm{~d}, J=6.8 \mathrm{~Hz}, \mathrm{POCH}_{2}\right), 62.6(\mathrm{~d}, J=5.8$ $\left.\mathrm{Hz}, \mathrm{POCH}_{2}\right), 53.0\left(\mathrm{CH}_{2}\right), 48.4(\mathrm{C}), 47.9(\mathrm{C}), 44.7(\mathrm{CH}), 38.3\left(\mathrm{CH}_{2}\right), 35.1$ (d, J $\left.J_{p} 136.3 \mathrm{~Hz}, \mathrm{PCH}_{2}\right), 32.9$ $\left(\mathrm{CH}_{2}\right), 26.6\left(\mathrm{CH}_{2}\right), 20.8\left(\mathrm{CH}_{3}\right), 20.0\left(\mathrm{CH}_{3}\right), 16.5\left(\mathrm{~d}, J_{p}=4.8 \mathrm{~Hz}, \mathrm{CH}_{3} \mathrm{CH}_{2}\right), 16.4\left(\mathrm{~d}, J_{p}=4.8 \mathrm{~Hz}, \mathrm{CH}_{3} \mathrm{CH}_{2}\right)$; LRMS $\left(\mathrm{ES}^{+}\right) \mathrm{m} / z 416\left(100 \%,[\mathrm{M}+\mathrm{Na}]^{+}\right)$; Elemental calcd. for $\mathrm{C}_{16} \mathrm{H}_{28} \mathrm{O}_{6} \mathrm{NSP}: \mathrm{C}, 48.85 ; \mathrm{H}, 7.17 ; \mathrm{N}, 3.56$. Found: C, 48.66; H, 7.05; N, 3.37. 


\section{Experimental for In Vitro Studies}

Cytotoxicity of Acetogenin analogues. An MTT cell viability assay ${ }^{3}$ was used to measure cytotoxicity against B16F10 murine melanoma cells (grown in RPMI 1640 with $5.0 \mathrm{mM} \mathrm{L-glutamine}$ and $10 \%$ (v/v) FCS). B16F10 cells were seeded in sterile 96-well microtitre plates at a seeding density of 104 cells $/ \mathrm{mL}$. Plates were incubated for $24 \mathrm{~h}$ and compounds $(0.2 \mu \mathrm{m}$ filter sterilised) were then added to give a final concentration of $0-0.15 \mathrm{mg} / \mathrm{mL}$ in $3 \%$ DMSO. After $67 \mathrm{~h}$ of incubation, MTT (20 $\mu \mathrm{L}$ of a $5 \mathrm{mg} / \mathrm{mL}$ solution) was added to each well, and the cells were incubated for a further $5 \mathrm{~h}$. After removal of the medium, the precipitated formazan crystals were dissolved in optical grade DMSO $(100 \mu \mathrm{L})$, and the plates were read spectrophotometrically at $550 \mathrm{~nm}$ after $30 \mathrm{~min}$ using a micro-titre plate reader. Cell viability was expressed as a percentage of the viability of untreated control cells, also grown in 3\% DMSO medium.

Haemolytic activity of acetogenin analogues. Freshly prepared acetogenin derivatives (3\% DMSO in PBS) at a range of concentrations $(0-0.3 \mathrm{mg} / \mathrm{mL})$ were plated $(100 \mu \mathrm{L})$ into non-sterile 96 -well microtitre plates. Blood was taken from an adult male Wistar rat $(\sim 250 \mathrm{~g})$, by cardiac puncture immediately after death (by $4 \% \mathrm{CO}_{2}$ asphyxiation) and placed in a lithium/heparinised tube $(10.0 \mathrm{~mL})$ on ice. Erythrocytes $(\mathrm{RBC})$ were isolated by centrifugation at $1500 \mathrm{x}$ g for $10 \mathrm{~min}$ at $4{ }^{\circ} \mathrm{C}$ (repeated 3 times). Using the final pellet, a $2 \% \mathrm{w} / \mathrm{v}$ RBC solution was prepared with pre-chilled PBS and it was added $(100 \mu \mathrm{L})$ to the previously prepared microtitre plates containing the test compounds. The plate was then incubated for $1 \mathrm{~h}$ at $37{ }^{\circ} \mathrm{C}$ before centrifugation at $1500 \mathrm{xg}$ for $10 \mathrm{~min}$ at room temperature. The supernatant was then placed in another 96well microtitre plate and haemoglobin $(\mathrm{Hb})$ release measured spectrophotometrically (OD550) using a microtitre plate reader (Tecan) using PBS as the blank. Hb release for each sample was expressed as a percentage of the release produced by $0.5 \% \mathrm{w} / \mathrm{v}$ Triton X-100, used as a reference control to produce $100 \%$ lysis. PBS and PBS with $3 \%$ DMSO were also used as controls. ${ }^{4}$

\footnotetext{
${ }^{3}$ Sgouras, D.; Duncan, R. J. Mat. Sci.: Materials in Medicine 1990, 1, 61-68.

${ }^{4}$ Duncan, R.; Bhakoo, M.; Riley, M. L.; Tuboku-Metzger, A. In Progress in Membrane Biotechnology; Gómez-Fernández, J. C., Chapman, D., Packer, L. Eds.; Birkhauser Verlag: Basel, 1991; p 253.
} 


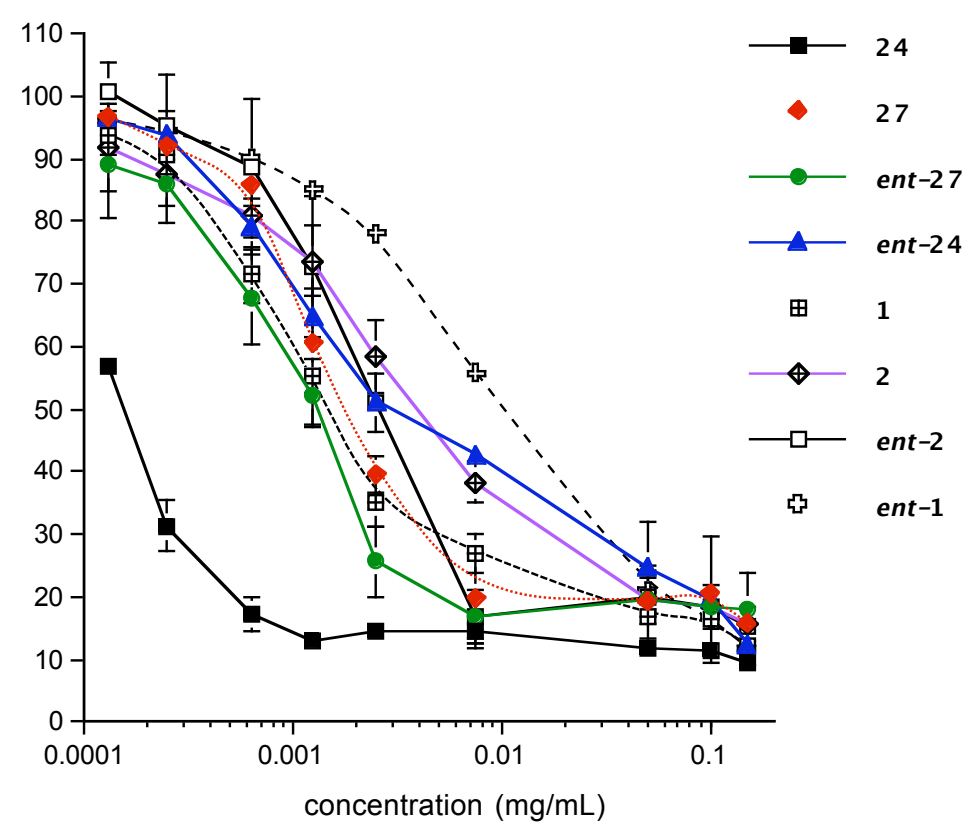

Figure 1. $\mathrm{IC}_{50}$ values against B16F10 cell line for acetogenin derivatives, seeding density 5 x $104 \mathrm{cells} / \mathrm{mL}, 3 \%$ DMSO in media, $(\mathrm{n}=3$, mean $\pm \mathrm{SD})$.

a/

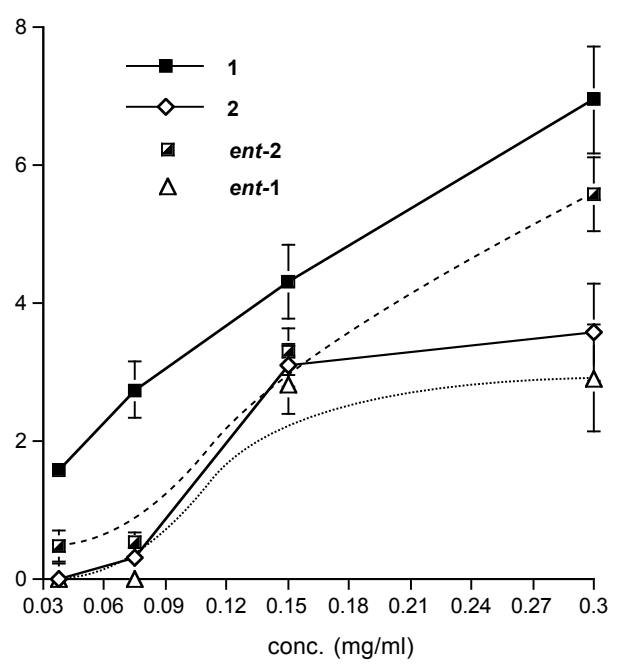

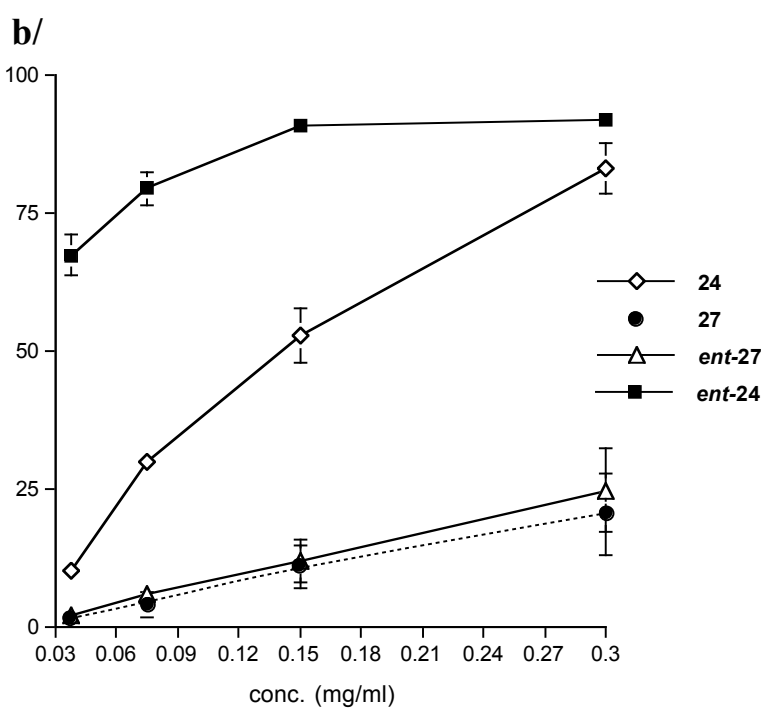

Figure 2. 1h Red Blood Cell Lysis Assay for acetogenin derivatives. a/ cis-solamin saturated derivatives b/ unsaturated derivatives. Haemolysis ( $\%$ control $1 \%$ Triton X-100), 3\% DMSO in PBS $(n=3$, mean \pm SE). 
General Methods. ${ }^{1} \mathrm{H}-\mathrm{NMR}$ and ${ }^{13} \mathrm{C}-\mathrm{NMR}$ were recorded on a 300 or $400 \mathrm{MHz}$ spectrometer (300 or 400 $\mathrm{MHz},{ }^{1} \mathrm{H}-\mathrm{NMR}$ respectively and 75 or $100 \mathrm{MHz},{ }^{13} \mathrm{C}$-NMR respectively) in deuteriochloroform $\left(\mathrm{CDCl}_{3}\right)$ with chloroform ( $\left.\square 7.26 \mathrm{ppm}{ }^{1} \mathrm{H}, \square 77.00 \mathrm{ppm}{ }^{13} \mathrm{C}\right)$ as the internal standard. Infrared (IR) spectra are reported in wavenumbers $\left(\mathrm{cm}^{-1}\right)$. Melting points were obtained in open capillary tubes and are uncorrected. All nonaqueous reactions were carried out under an inert atmosphere, in oven-dried glassware. The following solvents were distilled before use: THF (from Na/benzophenone) and $\mathrm{CH}_{2} \mathrm{Cl}_{2}$ (from $\mathrm{CaH}_{2}$ ) and where appropriate, other reagents and solvents were purified by standard techniques. TLC was performed on glassbacked plates coated with silica gel 60 with an $\mathrm{F}_{254}$ indicator; the chromatograms were visualised under UV light and/or by staining with phosphomolybdic acid (20\% solution in ethanol) or $\mathrm{KMnO}_{4}$. Flash column chromatography was either performed with 40-63 $\square \mathrm{m}$ silica gel (Merck) in standard glass columns or using pre-packed columns on a FlashMaster Personal Chromatography apparatus supplied by Jones Chromatography. 


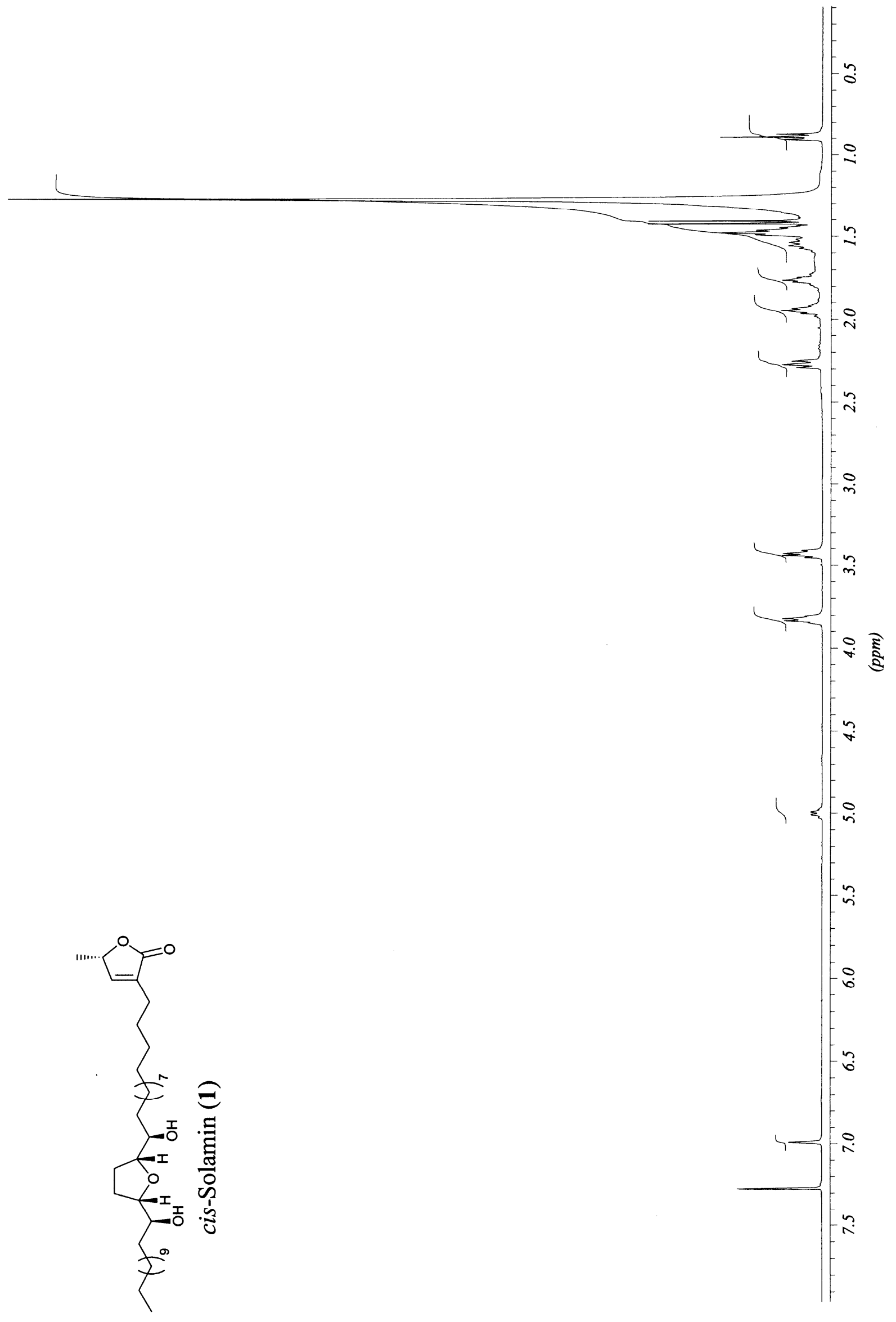




$$
4
$$




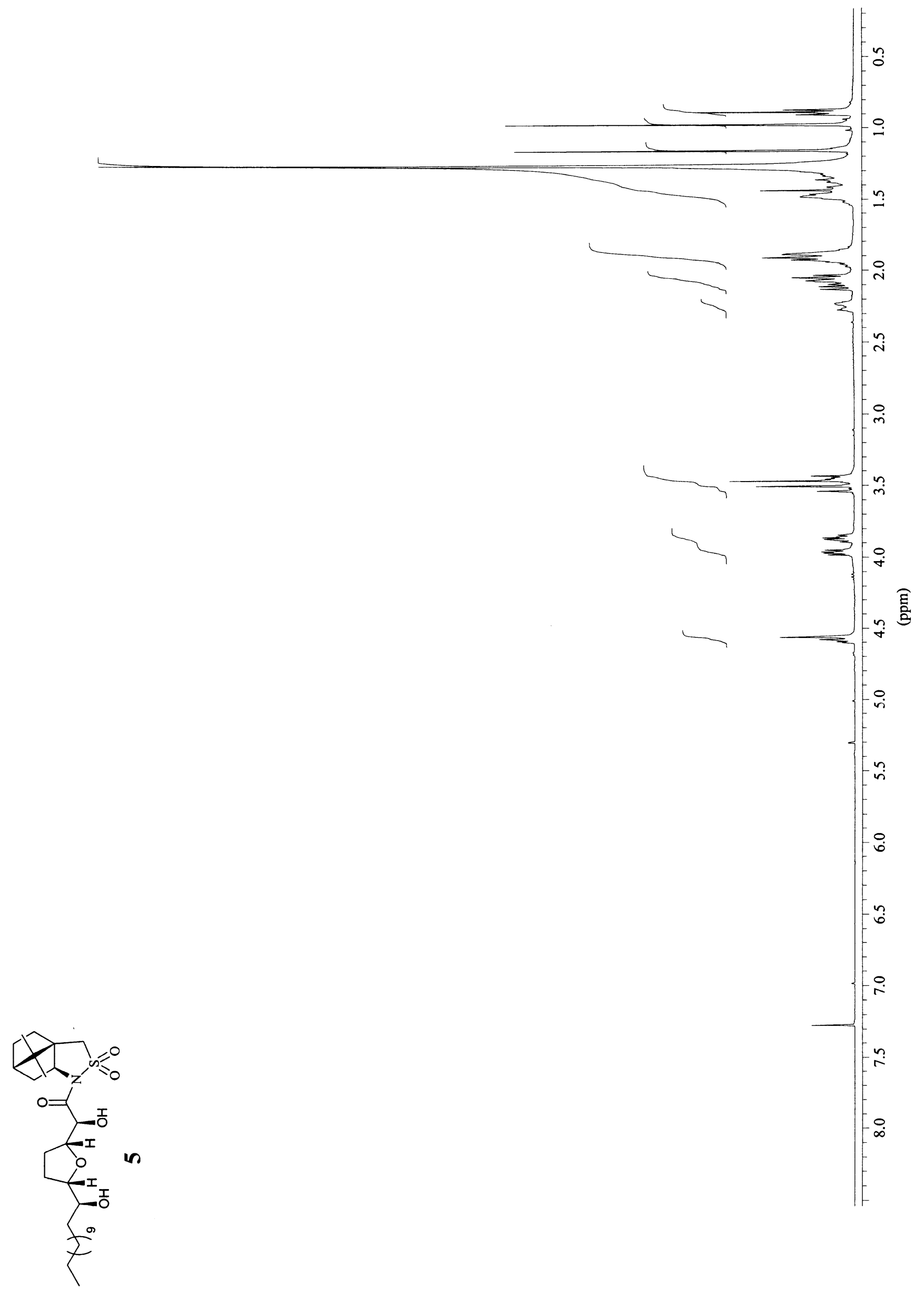




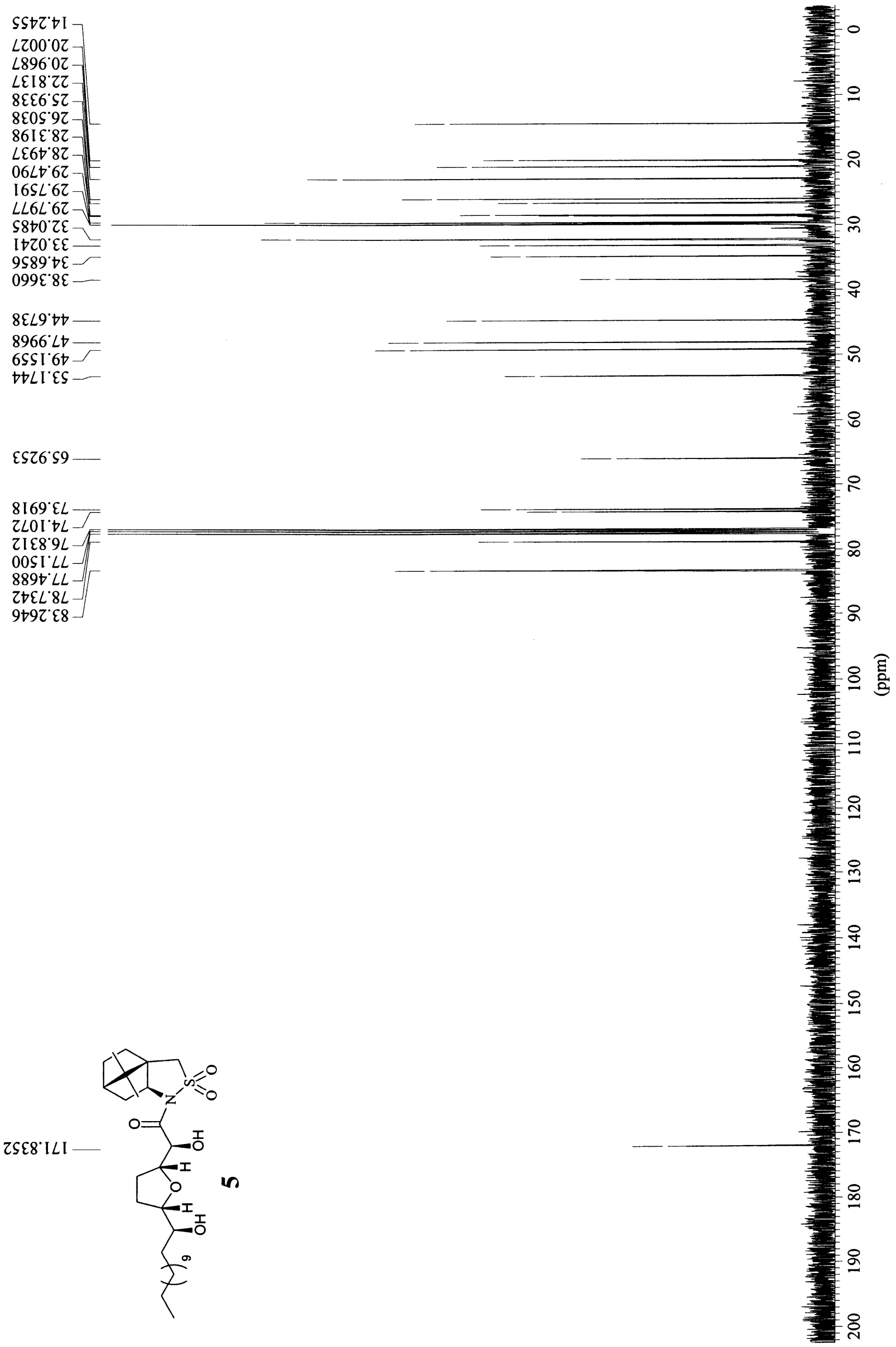




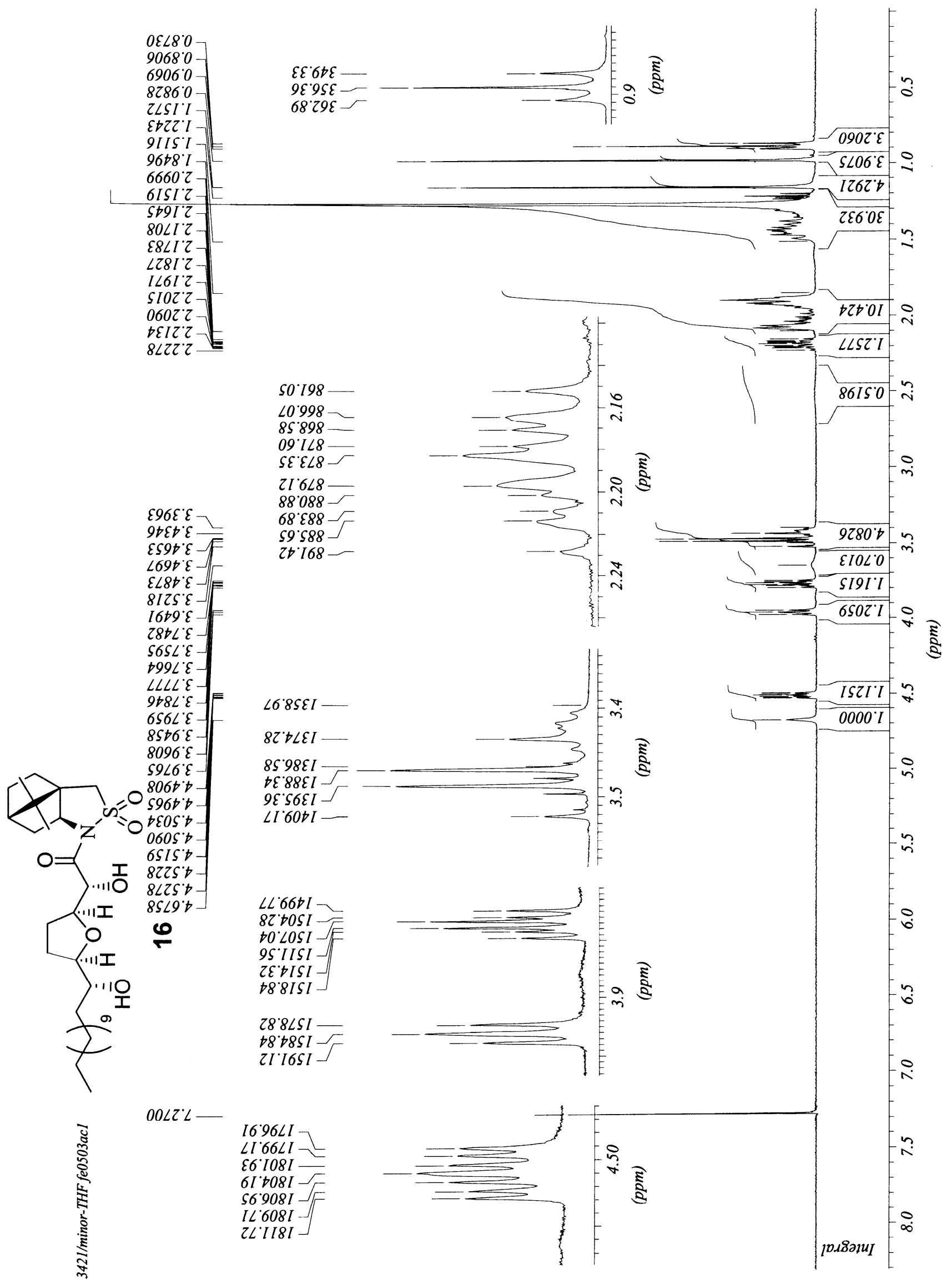



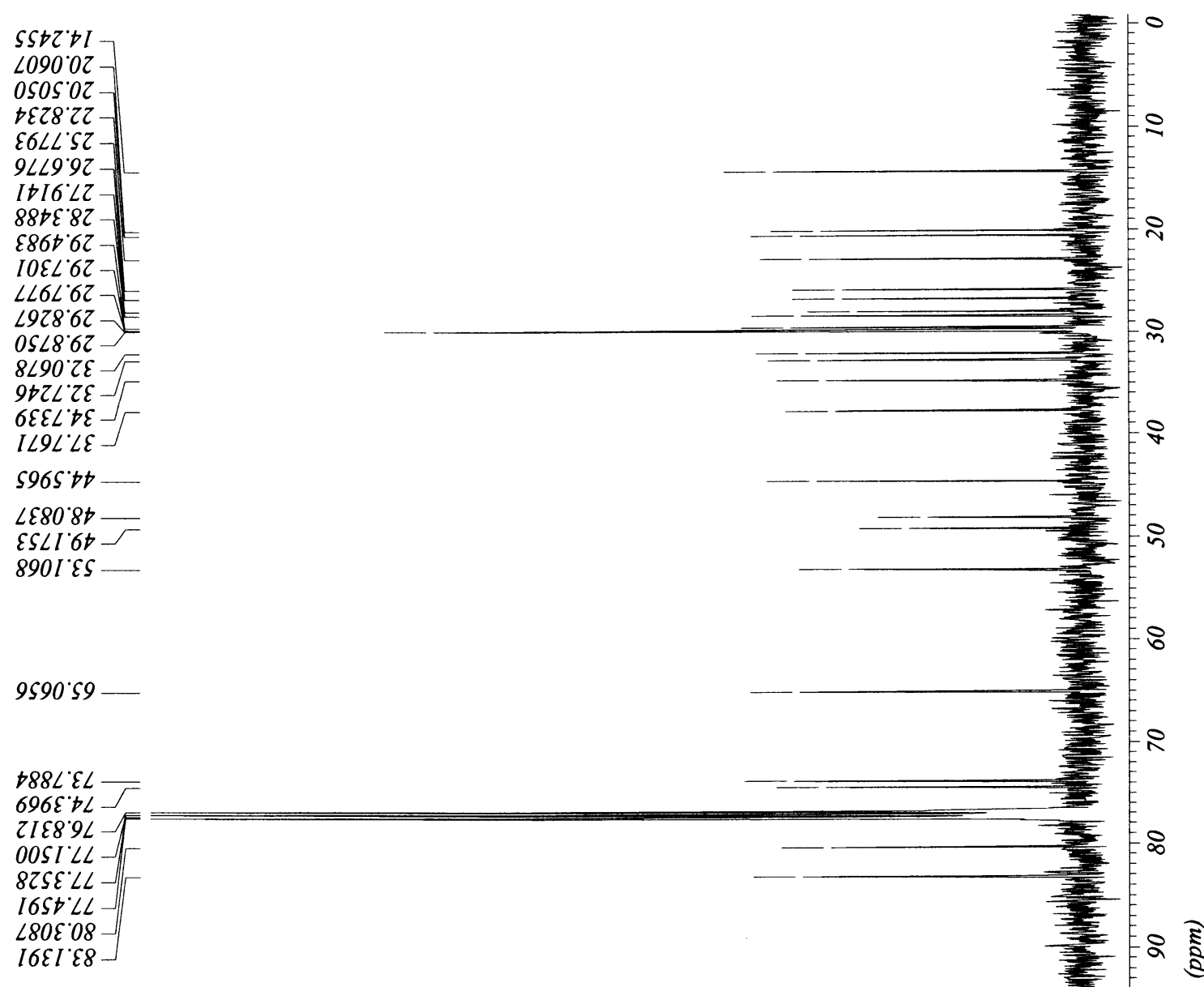

688L'EL

ZIE8.9L OOSI LL

$8 Z S \varepsilon^{\circ} \angle L-$

I $6 S T$ ' $\angle L-$

$\angle 80 \varepsilon^{\circ} 08$

I6EI $\mathcal{E} 8$

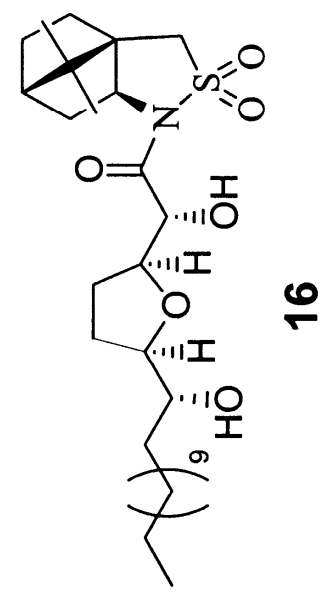

$8+9 \tau^{\circ} \mathcal{E} L I$

בัँ 


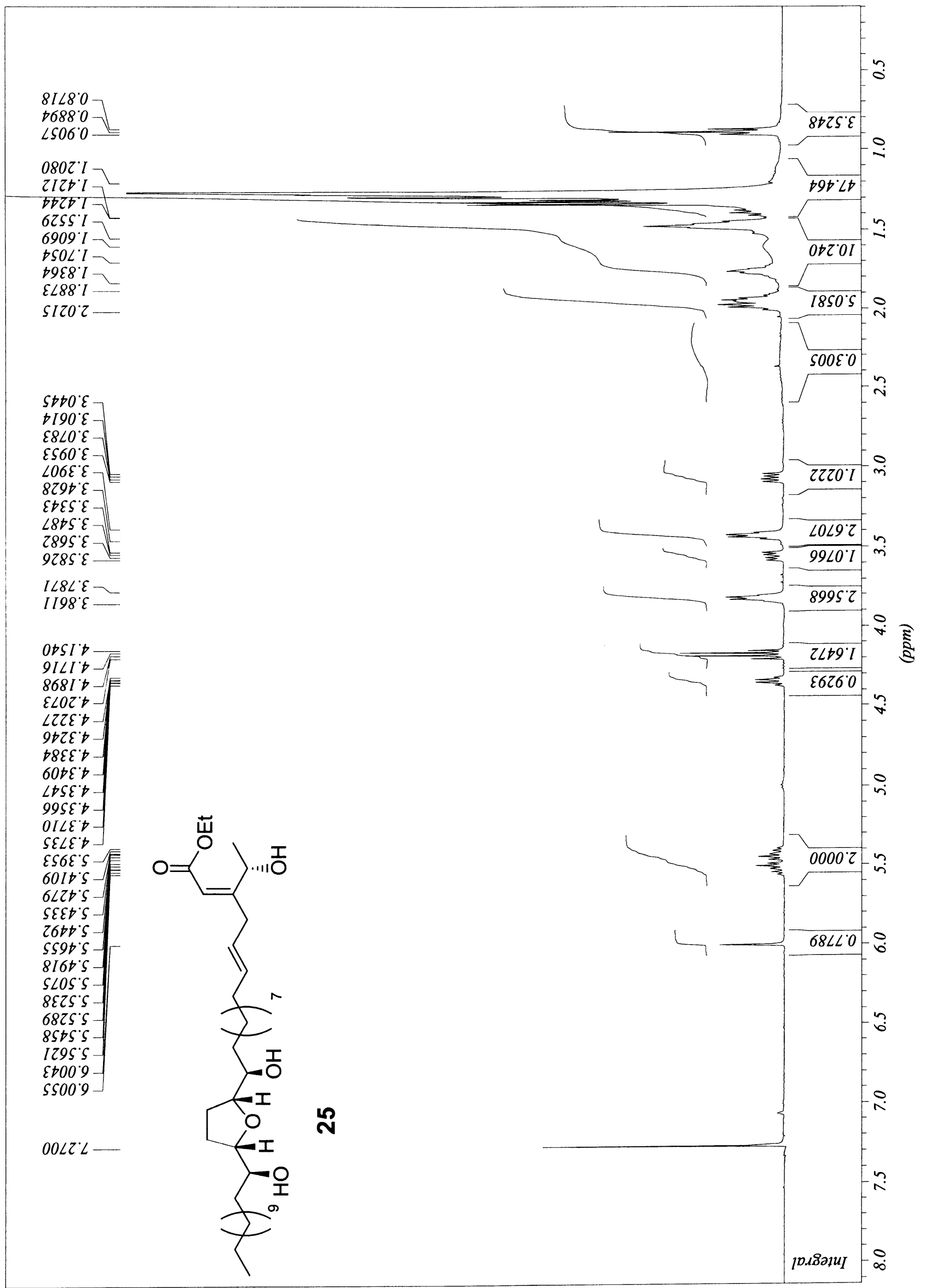




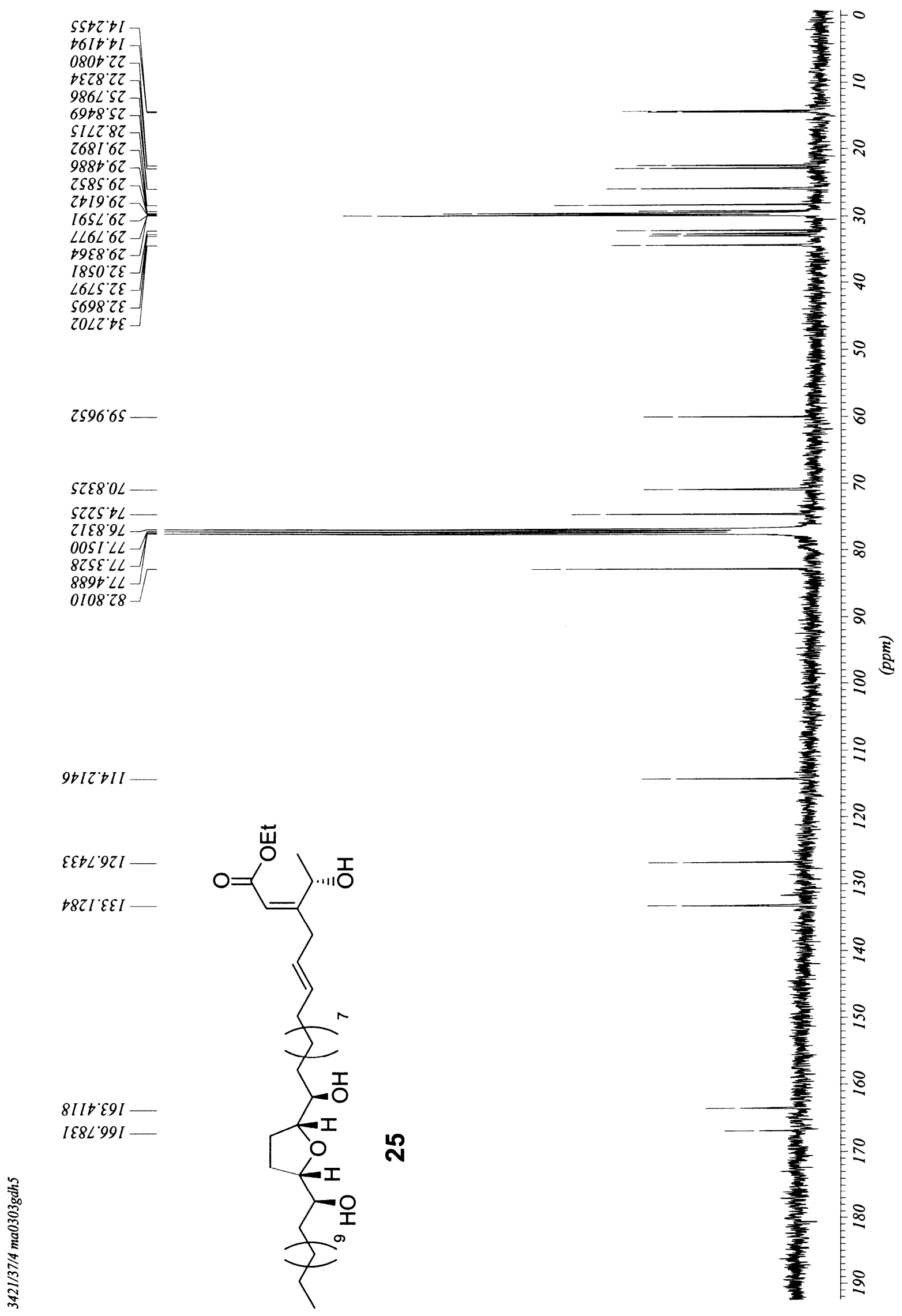




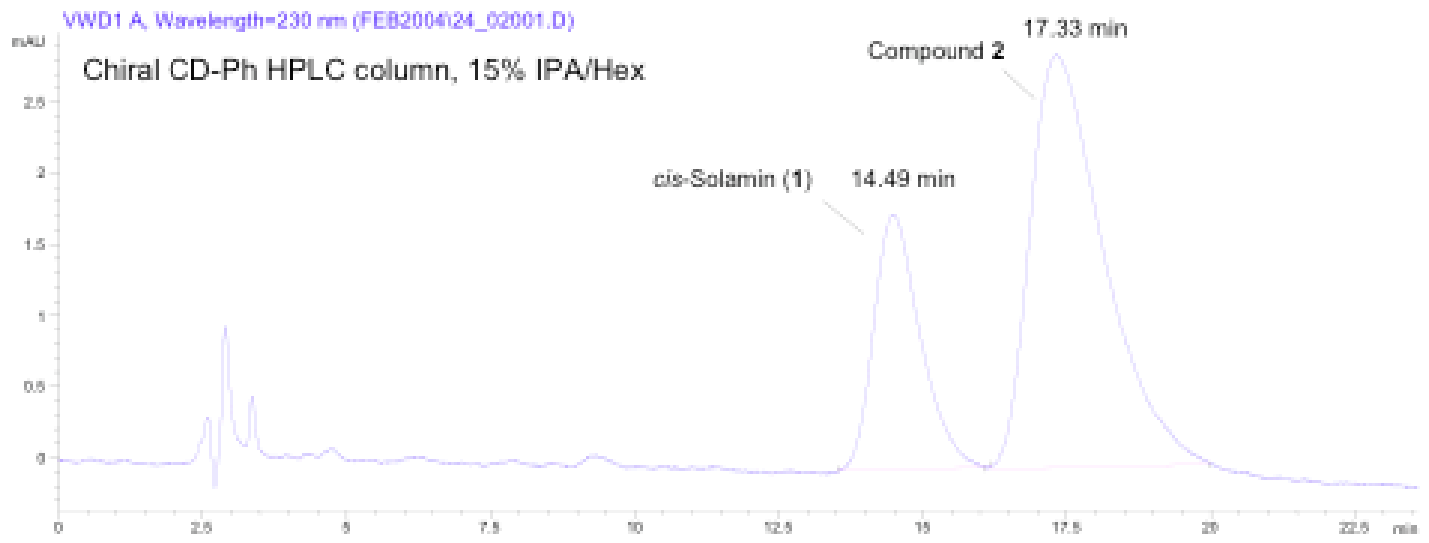

